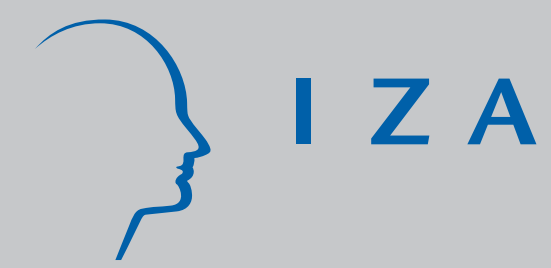

IZA DP No. 913

The Recent Economic Performance of Ukrainian Immigrants in Canada and the U.S.

Sergiy Pivnenko

Don DeVoretz

October 2003 


\title{
The Recent Economic Performance of Ukrainian Immigrants in Canada and the U.S.
}

\author{
Sergiy Pivnenko \\ Simon Fraser University \\ Don DeVoretz \\ Simon Fraser University and IZA Bonn \\ Discussion Paper No. 913 \\ October 2003
}

\author{
IZA \\ P.O. Box 7240 \\ D-53072 Bonn \\ Germany \\ Tel.: +49-228-3894-0 \\ Fax: +49-228-3894-210 \\ Email: iza@iza.org
}

This Discussion Paper is issued within the framework of IZA's research area Mobility and Flexibility of Labor. Any opinions expressed here are those of the author(s) and not those of the institute. Research disseminated by IZA may include views on policy, but the institute itself takes no institutional policy positions.

The Institute for the Study of Labor (IZA) in Bonn is a local and virtual international research center and a place of communication between science, politics and business. IZA is an independent, nonprofit limited liability company (Gesellschaft mit beschränkter Haftung) supported by Deutsche Post World Net. The center is associated with the University of Bonn and offers a stimulating research environment through its research networks, research support, and visitors and doctoral programs. IZA engages in (i) original and internationally competitive research in all fields of labor economics, (ii) development of policy concepts, and (iii) dissemination of research results and concepts to the interested public. The current research program deals with (1) mobility and flexibility of labor, (2) internationalization of labor markets, (3) welfare state and labor market, (4) labor markets in transition countries, (5) the future of labor, (6) evaluation of labor market policies and projects and (7) general labor economics.

IZA Discussion Papers often represent preliminary work and are circulated to encourage discussion. Citation of such a paper should account for its provisional character. A revised version may be available on the IZA website (www.iza.org) or directly from the author. 
IZA Discussion Paper No. 913

October 2003

\section{ABSTRACT}

\section{The Recent Economic Performance of Ukrainian Immigrants in Canada and the U.S.*}

This paper explores the relative success of ethnic and immigrant Ukrainians in Canada and in the United States. We found evidence for both a sheepskin and citizenship effects, which partially explains the strong economic performance of Ukrainian immigrants in Canada. Ukrainian immigrants to the U.S. are overachievers relative to all groups, which sheds light on Borjas thesis that self-selection and not immigration policy sorts immigrants between Canada and the U.S.

JEL Classification: J61, J31

Keywords: immigration, earnings, ethnicity, assimilation

Corresponding author:

Sergiy Pivnenko

Centre of Excellence: Immigration

WMX 4647

Simon Fraser University

Burnaby, BC, V5A 1 S6

Canada

Email: spivnenk@sfu.ca

*We thank Dennis Maki and the participants at the IZA Seminar of June 18, 2003 for their comments. 


\section{Introduction}

Academic studies of Ukrainian immigrants in North America have been devoted to their historical, linguistic or cultural experiences. With the exception of a recent sociological study of Ukrainian immigrants in the Toronto area (Isajiw et al. 2002), the literature does not discuss the economic performance of Ukrainians in North America.

The motivation for this paper is twofold: to extend the literature exploring possible ethnic and foreign birth effects on labour market performance, and to add to the limited economic studies of Ukrainian immigrants in Canada.

The dominate theme in the immigrant earnings literature is that most immigrants are subject to some economic penalties upon entry, and earn lower earnings relative the native- born. However, a few studies have emerged recently that isolate the phenomenon of "overachievers". We define "overachievers" in the economic context as immigrants who earn a positive premium upon arrival and subsequently outperform their native-born cohort.

In this context we investigate whether or not Ukrainian immigrants to Canada are overachievers, and then we ask if this result also holds for Ukrainians in the United States. Finally, anticipating a differential performance across the two countries, we speculate if self-selection or immigration policy has led to the distribution of Ukrainian immigrants between Canada and the United States. In this manner we can partially address Borjas hypothesis that immigrant self-selection and not immigrant selection policy determines where the most productive immigrants settle. ${ }^{1}$

I.

${ }^{1}$ See Borjas 1987, 1990, 1993. 


\section{Literature and Methodology Review}

The goal of this paper is to answer two related questions, namely, what is the influence of foreign-birth status and ethnicity on the earnings performance of Ukrainians in Canada? Next, what explains the anticipated differential earnings performance of Ukrainian immigrants across North America? The literature review in this paper, therefore, will be organized around these two analytical points.

Ethnic earnings studies in Canada have been traditionally limited in scope. For example, research by Swidinsky (1997), and Stelcner and Kyriazis (1995) focus primarily on analyzing wage differentials between "whites," visible minorities and aboriginal Canadians. Pendakur and Pendakur (1998) show that visible minority workers in Canada, including both Canadian born and foreign born, generally earn less than their "white" counterparts after controlling for several important income-enhancing characteristics such as occupation, education and knowledge of an official language. In particular, Pendakur and Pendacur conclude:

Although we find large differentials between whites and visible minorities, our research also points to substantial heterogeneity within these groups. Lumping all the white ethnic groups together or combining all the visible-minority ethnic groups together does not do justice to the complexity of ethnicity-based earnings differentials. (544)

Only a handful of case studies exclusively focus on the economic performance of immigrants by ethnic status including Chiswick $(1983,1993)$ on Jews in the U.S., DeVoretz and Dean (1996) on Jews in Canada; Suzuki (2002) on the Japanese in the US and Blackaby et al. (1997) on Indians, Black Caribbeans and Pakistanis in the U.K. This 
limited focus on ethnicity is possibly owing to the argument that racial or visible minority status, rather than ethnicity, is generally a more important predictor of immigrant income levels (Boyd 1992; Li 1992; Pendakur and Pendakur 1998).

The central analytical tool that addresses the primary issue in this paper, immigrant earnings relative to Canadian earnings experience, is the traditional assimilation model owing to Barry Chiswick (1978).

Immigrants are subject to some economic penalties upon entry initially and thus earn a lower income relative to their Canadian-born cohort. However, over time immigrants' earnings increase with their length of stay reflecting a positive assimilation process until they catch up to their cohort's earnings.

But this earnings deficit upon entry does not always appear, and using a traditional methodology DeVoretz and Dean (1996) investigate the possibility that selected immigrant groups earn a positive premium upon arrival and subsequently outperform their Canadian-born counterparts. As our preliminary investigation suggests, Ukrainian immigrants may belong to this overachieving group. Thus, this paper's particular challenge will be to adapt this assimilation methodology for the Ukrainian case.

The economic impact of ethnicity is further complicated since a citizenship affect may appear. Obviously all the Canadian born Ukrainians are Canadian citizens while 
only a fraction of Ukrainian immigrants are. Thus an earnings differential can arise due immigrants' citizenship status and not their foreign birth status. ${ }^{2}$

In sum, the investigation of ethnic effects on the economic success of immigrants poses demanding requirements on data quality. In addition to ethnic identity, citizenship status and commonly used human capital characteristics, such as age/experience and years of schooling, we also need a number of immigrant-specific characteristics that may not be available in the same data set. ${ }^{3}$ We describe the available control variables below.

Education is traditionally included as one of the important control variables in recent research on ethnic inequality in Canada (Boyd 1992; Isajiw, Sev'er and Driedger 1993; Pendakur and Pendakur 1998; Reitz and Breton 1994). This research has demonstrated that Canadian ethnic group income differentials are substantially reduced or eliminated when the effects of education are controlled. DeVoretz and Dean (1996) in their study of economic performance of ethnic Jews confirm that the observed large earnings advantages of Canadian Jews can be attributed mainly to their greater educational attainments in comparison to other ethnic groups.

Although it is widely accepted that disparities in education contribute to poor labour market outcomes the literature offers evidence of non-linearities, defined as a "sheepskin effect" (Jaeger and Page 1996). According to the market signaling theory, a

I.

${ }^{2}$ For example, Bratsberg et al (2002) investigated the effect of naturalization on earnings assimilation into the U.S. labour market of young male immigrants. We will also test for this effect in the Ukrainian context. ${ }^{3}$ For instance, immigrant admission class (economic, family, refugee) is a significant predictor of an immigrant's ability to experience earnings catch-up. Unfortunately, the census data, used here omits this important variable while containing many other important control variables. 
"sheepskin effect" is a wage return specific to educational credentials rather than to the accumulated years of education. ${ }^{4}$

Given this growing literature on the importance of the recognition of foreign credentials, this paper will emphasize the sheepskin effect for the Ukrainian ethnic group.

In order to complete the economic portrait of Ukrainian immigrants in Canada, we widen our perspective by including an analysis of Ukrainians who enter the U.S. labour market. In particular, we pose a speculative question: is the anticipated crossborder earnings difference owing to endowed characteristics of the two resident Ukrainian groups or not? In other words, do better economically endowed Ukrainian immigrants self-select to the U.S.?

In sum, this literature review has established that there exists a limited literature on immigrant overachievers and directs the methodology this paper must employ to investigate overachieving by ethnic groups. In addition, the standard discrimination literature provides a methodology owing to Blinder (1973) and Oaxaca (1973) to separate out ethnic versus foreign-birth status effects. Finally, using this methodology we can explore the effect of Canadian immigration policy vis-à-vis the US policy on sorting Ukrainian immigrant arrivals to North America.

\section{Economic Performance of Ethnic Ukrainians in Canada}

I.

\footnotetext{
${ }^{4}$ Ferrer and Riddell (2002) provide an empirical test for the role of credentials in the Canadian labour market. Their study of the Canadian-born population reveals the presence of large sheepskin effects that increase with a higher level of educational attainment. Betts and Lofstrom (1998), in their investigation of the US labour market, found that sheepskin effects influence earnings in different ways for natives and immigrants. Their findings suggest that sheepskin effects for graduating from college are greater for immigrants than natives, but smaller for the completion of secondary school.
} 


\subsection{Canadian data}

The Canadian data are collected from the 1996 Canadian Census. The populations selected as a sample includes all males and females residing in central and western Canada. The sample is restricted to individuals aged 18 to 65 who reported wage and salary incomes in $1995 .^{5}$ Outlaying observations are also excluded from the sample. ${ }^{6}$

The sample is further divided into four groups based on an individual's ethnic background: i) Ukrainian Immigrants (UI), ii) Non-Ukrainian Immigrants (NUI), iii) Ukrainian Canadian-born (UCB), and iv) Non-Ukrainian Canadian-born (NUCB). In this paper we use $541 \mathrm{UI}, 63,162 \mathrm{NUI}, 11,950 \mathrm{UCB}$ and 242,727 NUCB observations respectively. $^{7}$

\subsection{Descriptive Analysis}

Table 1 reports some socio-economic characteristics for Ukrainians, all Canadian immigrants, and the Canadian born categories. Our census based data suggest that in 1995 Ukrainian immigrants to Canada earned higher average wage incomes than other Canadian immigrants, whereas Canadian born Ukrainians were as successful as rest of the Canadian born. In fact both non-Ukrainian immigrants and Ukrainian immigrants earned lower income their Canadian born counterparts. According to the human capital I.

${ }^{5}$ Those who were self-employed or unemployed, and those who obtained income solely from other sources such as government transfer payments and capital gains are excluded from the sample.

${ }^{6}$ In terms of wage and salary income, there are some unreasonable figures such as $\$ 12$ per year. This may be due to the confusion of the respondents who claimed an hourly wage, instead of an annual wage.

${ }^{7}$ Since this paper has employed the Public Use Microdata File (PUMF) of the 1996 Canadian Census, which in turn contains 2.8 percent of 1996 Canadian Census data, the total observations for these four categories, 318,380 observations, reflect approximately 11,370,714 individuals who would have met the criteria stated above (if 100 percent of Census data are used), which is about one-third of the total Canadian population in 1996. 
theory, the observed wage earnings differences could be explained by the difference in human capital and demographic characteristics ${ }^{8}$.

As we have argued the immigrant selection process is also an important determinant of wage differentials between immigrant groups. The Canadian immigration system screens selected skilled immigrants based on the assessment of their human capital characteristics. Figures 1 and 2 report that only 30 percent of non-Ukrainian immigrants pass through this selection system in 1991-2001, whereas more than 60 percent of ethnic Ukrainians entered Canada as skilled workers.

The descriptive statistics in table 1 indicate that regardless of ethnicity immigrants are more likely to be legally married and are older than the Canadian born working population. In contrast to the demographic characteristics, immigrant human capital attributes display a greater variability across ethnic status. All immigrants in general, and Ukrainian immigrants in particular, report higher educational levels (a greater proportion of university degrees). Ukrainian immigrants also demonstrate a greater tendency to speak an official language at home. ${ }^{9}$ The proportion of Anglophones is substantially larger for the Canadian born Ukrainians (98.5 percent). ${ }^{10}$ Finally, among all population groups Ukrainian immigrants have largest (smallest) proportion of professionals.

I.

${ }^{8}$ Given approximately the same number of weeks worked.

${ }^{9}$ Regardless of their place of birth, ethnic Ukrainians report less knowledge of French. This linguistic pattern could explain the choice of the province of destination. According to figures 3 and 4, recent Ukrainian immigrants are more likely to land in Ontario and less likely to settle in Quebec then immigrants of other ethnicity.

${ }^{10}$ They are descendants of the first waves of Ukrainian immigrants who settled mainly in English speaking Prairies. 


\subsection{Initial Regression Analysis}

In this section we briefly report the results of testing a human capital model to describe the earnings experiences of four population groups. The following regression analysis isolates the effect of age on wage income while controlling for a number of variables, and test whether determinants of the wage earnings of Ukrainians in Canada conform to the traditional human capital model.

For both groups of Canadian born we specify the following log-linear relationship:

Equation 1.

lnwage $=\mathrm{f}$ (age, age squared, female, married, education attainment dummies (dipl, bach, bachpl, phd), occupational dummies (skl, prof), lnwkswk),

where:

age - individual's age; female - dummy for females ${ }^{11}$; married - dummy for the married; dipl, bach, bachpl, phd - educational credentials dummies; skl-dummy for skilled occupation; prof - dummy for professional occupation; lnwkswk - natural logarithm of weeks worked.

In this model the dependent variable lnwage, or the natural logarithm of annual wage earnings, is determined by the degree of human capital accumulated (age as a proxy for experience, and education) and the relevant demographic characteristics (marital status and gender) conditioned on weeks worked and occupational choice.

I.

11 Because of the data limitations, namely the small sample for Ukrainian immigrants, we cannot run separate regressions for males and females. Instead, we include a dummy variable to capture a gender effect in the difference of the intercepts. 
The age and age squared variables are included into the earnings equation in order to capture two effects. First, age is a proxy for the impact of labour market experience, and age squared measures the diminishing return to productivity (earnings) owing to age. We expect positive signs for the age, credential and occupational variables, married, lnweeks, and negative signs for the age squared and female variables.

For the immigrants groups we augment Equation 1 to take into account language skills, and other factors, such as cultural adaptability and their knowledge of Canadian labour market, which will condition the size of the entry effect (constant term) and the assimilation process.

Thus, the earnings function for foreign born is specified as follows:

\section{Equation 2}

Lnwage $=\mathrm{f}$ (age, age squared, married, female, dipl, bach, bachpl, phd, skl, prof, lnwkswk, a dummy representing knowledge of official language (oln), year since migration (ysim) and ysim squared)

The coefficients on ysim and ysim squared are predicted to be positive and negative respectively whereas a greater facility in an official language is expected to have a positive effect on wage earnings. The other variables are expected to obtain the same signs as in the Canadian-born case.

\section{Insert Table 2}

Table 2 summarizes our regression analysis for our four population groups. For nonUkrainian immigrants, Ukrainian Canadian born and non-Ukrainian Canadian born most estimated coefficients are significant and obtain the expected signs. However, marital status and educational level between bachelor and Ph.D. have an insignificant affect on Ukrainian immigrant earnings. 
The reported results also suggest that occupation and the number of weeks worked have the largest effect for the Ukrainian immigrant earnings, whereas as a university level educational credential is a more important earnings determinant for the Canadian-born group.

\subsection{Sheepskin effects}

In our initial analysis of the human capital model, we used the highest degree earned rather than the total years of schooling due to data considerations. ${ }^{12}$ Given this choice of an educational variable and the fact that Ukrainian immigrants on average demonstrate a higher educational attainment then other immigrants, we attempt to assess the role of education in earnings performance from a different perspective.

Signaling models yield a framework to better understand why labour markets provide greater incentives to some groups to acquire high-level credentials and less incentives to other groups. These signaling models rely on what is called the "sheepskin effect," which is an increase in earnings owing to a specific return to educational credentials rather than to the accumulated years of schooling. As noted earlier, other studies report large sheepskin effects or signals of high productivity (Belman and Heywood 1991) and the following analysis is intended to check if this is the case for Ukrainians.

Initially, for each of the four groups, we estimate the earnings equation in the traditional form of the log-linear function:

I.

${ }^{12}$ Census data on total years of schooling are grouped into several uneven intervals, which cannot be employed as a continuous measure. 


\section{Equation 3}

lnwage $=\mathrm{f}$ (age, age squared, female, married, dipl, bach, bachpl, phd, skl, prof, lnwkswk)

In this equation the dependent variable is the natural logarithm of annual earnings. In addition to the standard demographic and control variables, dummy variables defined earlier distinguish between the four types of credentials: diploma, bachelor, bachelor plus, and Ph.D. The coefficients on these dummies estimate the marginal effect for each level of education, as compared with the excluded group who have high school or lower qualifications. The initial test for sheepskin effects is based on a generalization of equation (3) with a string of dummy variables for years of completed education, $S_{i}$ added to the model. The coefficients on these dummy variables should capture any (possibly non-linear) returns to years of schooling, leaving the qualifications variables to capture any sheepskin effects (Jaeger and Page 1996).

For each population group we estimate two log-linear equations: with and without the credential variables with both models including dummy variables for the years of schooling. The sheepskin effect for the i-th year of schooling is calculated as the difference between the coefficients on the i-th year of schooling dummies from the two models.

Our results are summarized in Table 3

According to our estimates, immigrants experience a greater sheepskin effect at all educational levels except the highest. Among the two immigrant groups, Ukrainian immigrants experience the largest sheepskin effect. 


\subsection{Age earnings profiles (Canada)}

An age-earnings profile shows the relationship between the age and the average earnings of an individual, conditioned on other human capital characteristics, as they grow older in Canada. This paper analyzes age-earnings profiles for four groups: Ukrainian immigrants (UI), non-Ukrainian immigrants (NUI), Ukrainian Canadian-born (UCB) and non-Ukrainian Canadian-born (NUCB), holding variables such as gender, marital status, education and occupational skill constant. If age is treated as a proxy for experience, an age-earnings profile could be also interpreted as an "experience-earnings profile."

Figure 5 portrays the age-earnings simulated profiles of the four groups. ${ }^{13}$ As expected, all four age-earnings profiles exhibit an increasing return to experience at a decreasing rate, as the human capital theory would predict. Regardless of their ethnic background, two Canadian-born groups (UCB and NUCB) follow a similar pattern and reach their earnings maximum at the age of 46 .

As expected from human capital theory, both immigrant groups (UI and NUI) exhibit flatter profiles, and they reach their maximums later: UI at 55, and NUI at 50 years of age. In addition, earnings of Ukrainian immigrants peak higher than earnings of the non-Ukrainian immigrants. Furthermore, Ukrainian immigrants catch up to Canadianborn earnings earlier than non-Ukrainian immigrants. While Ukrainian immigrants reach

I.

\footnotetext{
${ }^{13}$ For each group we estimated log-linear equation similar to Equation 2 (years since immigration excluded). Age-earnings profiles were simulated using estimated coefficients on age and age squared with an intercept capturing all other productive characteristics estimated at their mean values.
} 
the catch-up point at the age of 52, non-Ukrainian catch up to the Canadian-born at age 56.

\subsection{Assimilation profiles (Canada)}

In order to further assess the earnings performance of Ukrainian immigrants, we estimate assimilation profiles for both immigrant groups.

Three general factors will determine relative immigrant earnings: i) the assimilation effect, period effect and ii) cohort effect. Assimilation effects occur while in residence in the destination country and can be characterized as an immigrant's eventual convergence to the labour market performance of the native-born. ${ }^{14}$ Figure 6 illustrates the assimilation effect for all Ukrainian immigrants entering Canada in all years as a function of the years since immigration. As in the case of age-earnings profiles, the intercept captures all other productive characteristics estimated at their mean values.

For Ukrainian immigrants, the assimilation process starts at a higher income level that exceeds the income earned by non-Ukrainian immigrants with the difference growing over time. The greater intercept reflects the more favorable entry effect for the Ukrainian immigrants. This positive earnings premium implies that the quality of the earnings-enhancing characteristics Ukrainians have acquired in their home country is relatively higher than for the rest of the immigrant population. It may also reflect a higher degree of transferability of skills across countries.

I.

${ }^{14}$ Period effects arise from the differences in the labour market conditions for immigrants arriving in different years. Unfortunately, given available sample sizes from only the 1996 Census, we are not able to separate the period and assimilation effects across cohorts. 


\subsection{Foreign birth or citizenship effect?}

Age-earnings profiles illustrated in figure 5 suggest that Ukrainian immigrants in Canada face an earnings penalty when compared to their Canadian born counterparts. Our approach so far argued that the lack of host country specific human capital is the only source of the observed earnings disparity between immigrants and the native born. Canadian citizenship however may provide a variety of economic benefits including access to the federal government labour market and any additional wage premiums paid by private Canadian employers. In order to access this possible contribution of Canadian citizenship to the earnings performance of Ukrainian immigrants we augment our model with a citizenship dummy which takes a unit value if an immigrant is a naturalized citizen, and zero otherwise.

The regression results displayed in table 4 confirm a significant earningsenhancing effect of citizenship. According to our estimates, holding other relevant factors constant, the value of Canadian citizenship to Ukrainian immigrants accounts for 23 per cent of expected increase in wage earnings, whereas for non-Ukrainian immigrants about 16 per cent. This earnings premium translates into a higher intercept for the ageearnings profile of Ukrainian immigrants who acquired Canadian citizenship. Figure 7 illustrates the age-earnings profiles of three groups representing ethnic Ukrainians: Canadian born, naturalized citizens and non-citizen immigrants. In fact the age-earnings profile for naturalized Ukrainians initially follows that of the Canadian born, catches up at age 45 , peaks later and slightly higher, and ends with higher earnings. The non-citizen foreign-born population in Canada exhibits a smaller intercept for their age-earnings profile and these non-citizens only catch up to Canadian born earnings at age of 60 . 


\section{Ukrainians in the U.S.?}

\subsection{U.S. data}

The 1990 US Census from IPUMS (Integrated Public Use Microdata System) database was employed to estimate the Ukrainian earnings functions in the U.S. ${ }^{15}$ Although U.S. and Canadian censuses differ in some minor aspects, they ask comparable questions and use similar variable definitions for our key variables.

As in the Canadian case we restrict our analysis to individuals aged between 18 and 65 who reported wage and salary incomes. The samples representing four population groups have the following sizes: Ukrainian immigrants - 1,890 observations, nonUkrainian immigrants - 473,577, Ukrainian US born - 15,222, non-Ukrainian US born $5,071,328$.

\subsection{Economic performance of ethnic Ukrainians in the US: An overview}

At this point we would like to establish if there is a differential earnings experience for Ukrainian immigrants across North America and why. Table 5 presents a brief summary of the performance of ethnic Ukrainians in the U.S. based on our familiar four-group framework.

The average wage statistic indicates that in 1989 Ukrainian immigrants outperformed all other population groups in the U.S. The magnitude of the Ukrainian immigrants demographic and human capital characteristics can rationalize this I.

\footnotetext{
${ }^{15}$ Steven Ruggles and Matthew Sobek et al. Integrated Public Use Microdata Series: Version 3.0 Minneapolis: Historical Census Projects, University of Minnesota, 2003 (http://www.ipums.org)
} 
phenomenon. First, a greater average age (45 vs. 37 ) suggests that Ukrainian immigrants have more work experience. Next, the percentage of the legally married is the highest for the foreign born Ukrainians. ${ }^{16}$ Third, Ukrainian immigrants were the most educated with 34 percent having a university education. ${ }^{17}$ Fourth, Ukrainian immigrants reported a better command of English than their non-Ukrainian counterparts (93 vs. 77 percent). Finally, Ukrainian immigrants were more likely employed in skilled or professional occupations than workers from the other population groups.

Using our earlier specifications and methodology, we construct age-earnings profiles for the United States. Figure 8 illustrates the critical point that ethnic Ukrainians born in the U.S. outperform non-Ukrainian immigrants and all other US-born population categories until age 50 when Ukrainian immigrants dominate all population groups.

Comparing the Canadian and the U.S. experience, we can conclude that Ukrainian immigrants, in terms of their performance relative to the other population groups, are doing better in the United States than in Canada. The question is why? We now turn to an analysis that will shed light on this question.

\subsection{Decomposition of the cross-country earnings differentials}

In order to compare the economic performance of ethnic Ukrainians across the U.S.-Canada border we use 1991 Canadian census and 1990 U.S. census micro data ${ }^{18}$.

I.

${ }^{16}$ Greater labour force attachment is associated with being married.

${ }^{17}$ Only 23 percent of non-Ukrainian immigrants and 22 percent of the non-Ukrainian U.S. born reported university degrees.

${ }^{18}$ Although the latest Canadian census data is available for 1996, there is no matching census data for the U.S., where censuses are conducted every ten years. Therefore, the closest match between the two countries occurs in 1990 (U.S.) and 1991 (Canada). 
Using the CPI and average 1990 exchange rate, we convert 1989 wages earned in US dollars into their 1990 Canadian dollar equivalent. Figure 9 illustrates the relative earnings performance of Ukrainian immigrants in the United States and Canada.

The diagram indicates a substantial earnings differential across the two countries. Is this differential explained by the difference in human capital endowments, or by other factors related to the cross-country variations in technological and labour market structures? Leaving aside the nature of the earnings differential not attributed to human capital characteristics, we first estimate how much of the observed earnings differential for Ukrainian immigrants resident in the two countries is explained by the difference in their human capital endowments. The result of this analysis will allow us to partially assess the effectiveness of immigration policies in Canada and the US in sorting out Ukrainian immigrants with the more productive human capital. Incidentally, this would also allow us to estimate the opportunity cost in terms of forgone earnings for Ukrainian immigrants who stay in Canada rather than move on to the US. ${ }^{19}$

According to the Blinder-Oaxaca methodology we employ, the wage differential between the two groups could be represented as the sum of the two components: one part attributed to the different earnings generating structure, the other - explained by the difference in human capital endowments. Traditionally, this approach has been used in studies of labour market discrimination, meaning that the first component represents the wage disadvantage due to discrimination. The particular challenge of this paper is to apply this framework to investigate the immigrants' selection process across the two I.

\footnotetext{
${ }^{19}$ This cross border movement is very easy after Ukrainian immigrants acquire Canadian citizenship given the NAFTA TN-1visa.
} 
countries, which is essentially a discrimination process. In our view, Canada with its more restrictive point-based assessment system "discriminates" against less skilled immigrants who plan to migrate to North America.

Given the Ukrainian immigrant wage earnings are generated in two different economies, we acknowledge the need for a strong technological assumption. Indeed, the higher labour productivity of Ukrainian immigrants observed in the United Stated could be explained by a higher total factor productivity or by a higher capital-labour ratio. If we invoke that all differences in technology between Canada and the United States is owing to Hicks-neutral differences, than the reported earnings estimates below will capture any technology difference in differences in the estimated coefficients in the earnings functions and will be noted as such when reported. ${ }^{20}$

We now turn to estimating the sources of earnings differences between Ukrainians resident in the US and Canada with earnings differential equation in the following matrix form:

Equation 4.

$\ln W_{U S}-\ln W_{C A N}=\bar{X}_{C A N}^{T}\left(\hat{\beta}_{U S}-\hat{\beta}_{C A N}\right)+\left(\bar{X}_{U S}-\bar{X}_{C A N}\right)^{T} \hat{\beta}_{U S}$

where

$\hat{\beta}_{C A N}$ - vector of the estimated coefficients for Canadian sample;

$\hat{\beta}_{U S}$ - vector of the estimated coefficients for the US sample;

$\bar{X}_{C A N}$ - vector of mean values of explanatory variables for the Canadian sample;

$\bar{X}_{U S}$ - vector of mean values of explanatory variables for the US sample;

I.

${ }^{20}$ Hicksian neutrality implies that production function of one country equals production function of the other country multiplied by a constant. 
$\hat{\beta}_{U S}-\hat{\beta}_{C A N}$ - difference in the wage generating structure between the US and

Canada;

$\bar{X}_{U S}-\bar{X}_{C A N}$ - difference in the human capital endowments between the Ukrainian immigrants in Canada and their American counterparts.

The first term in the right-hand side of this equation represents an earnings differential that is not explained by the difference in productive characteristics. In the context of our study this could be interpreted as the wage premium for a Ukrainian immigrant in Canada moving to the US. The second term represents an earnings differential due to the higher human capital endowments for the Ukrainian immigrants in the US. ${ }^{21}$ Variances of the estimates of those components are calculated according to the following formulas:

$$
\begin{aligned}
& \operatorname{var}\left[\bar{X}_{C A N}^{T}\left(\hat{\beta}_{U S}-\hat{\beta}_{C A N}\right)\right]=\bar{X}_{C A N}^{T}\left[\operatorname{var}\left(\hat{\beta}_{U S}\right)+\operatorname{var}\left(\hat{\beta}_{C A N}\right)\right] \bar{X}_{C A N} \\
& \operatorname{var}\left[\left(\bar{X}_{U S}-\bar{X}_{C A N}\right)^{T} \hat{\beta}_{U S}\right]=\left(\bar{X}_{U S}-\bar{X}_{C A N}\right)^{T} \operatorname{var}\left(\hat{\beta}_{U S}\right)\left(\bar{X}_{U S}-\bar{X}_{C A N}\right)
\end{aligned}
$$

For Ukrainian immigrants in Canada and in the US we estimate vectors

$\hat{\beta}_{U S}, \hat{\beta}_{C A N}, \bar{X}_{U S}, \bar{X}_{C A N}$ using the log-linear equation specified earlier.

Our calculations indicate that 19 percent of the 22.5 percent earnings advantage of Ukrainian immigrants in the US over their Canadian counterparts, is owing to the greater endowment of human capital for Ukrainian immigrants resident in the U.S. and only 3.5 percent is explained by other factors. $^{22}$

I.

${ }^{21}$ In this application of Oaxaca-Binder technique we consider the U.S. wage structure as a benchmark.

22 The estimated human capital component was found statistically significant with standard deviation 1.71. The estimated effect of other factors, including technology, was small and its contribution to the wage differential was statistically insignificant with standard deviation 3.67. 


\section{Conclusions}

Our study of economic performance of Ukrainian immigrants based on 1996 Canadian census data suggests that among all immigrants entering Canada Ukrainians demonstrate above average economic performance in terms of their wage earnings. The relative success of Ukrainian immigrants could be explained by greater official language abilities, a more favorable occupational distribution, and greater education. These effects translate into a higher peaked age-earnings profile, a faster rate of assimilation and an earlier catch up age with respect to Canadian born earnings. In addition, compared to other immigrants Ukrainians enjoyed a greater earnings-enhancing effect from obtaining Canadian citizenship. In fact, the lifetime earnings pattern for naturalized Ukrainians is similar to the Canadian born cohort.

Our findings also show that Ukrainian immigrants tend to experience a larger sheepskin effect than the rest of the Canadian immigrant population. This suggests that Canadian employees value a Ukrainian degree more than other foreign degrees. We also found that Ukrainian ethnicity alone makes no difference, in terms of earnings performance, for a Canadian-born ethnic Ukrainian.

In contrast to their Canadian experience, the economic success of Ukrainians in the United States is more pronounced. Ukrainian ethnicity in both foreign and US-born populations yields substantially higher age-earnings profiles than the aggregate of the rest of the ethnic groups.

The cross-country comparison of the labour market performances suggests that more productive Ukrainian immigrants enter the U.S. contrary to what a naïve analysis of 
two countries immigration policies would suggest. This offers support to Borjas view that more skilled immigrants self-select to enter the U.S. regardless of the immigrant screening device employed by Canada. In short, the Canadian selection system fails to attract Ukrainian immigrants with greater human capital. Thus, there exist little economic incentive for Ukrainian immigrant resident in Canada to move the United States. 


\section{References}

Belman, D. and J. Heywood. 1991. Sheepskin effects in the returns to education: an examination of women and minorities. Review of Economics and Statistics 73 (4): 720-724.

Betts, J. and M. Lofstrom. 1998. The Educational Attainment of Immigrants: Trends and Implications. NBER Working Paper.

Blackaby, D., D. Leslie, P. Murphy, and N. O’Leary. 1998. The ethnic wage gap and employment differentials in the 1990s: Evidence for Britain. Economics Letters 58: $97-103$.

Blinder, A. 1973. Wage Discrimination: Reduced Form and Structural Estimates. Journal of Human Resources 8: 436-55.

Borjas, G. 1987. Self-Selection and the Earnings of Immigrants. American Economic Review 77 (4): 531-51.

1993. Immigration Policy, National Origin, and Immigrant Skills: A Comparison of Canada and the United States. In Small Differences that Matter: Labor Markets and Income Maintenance in Canada and the United States, edited by David Card and Richard Freeman. University of Chicago Press.

- 1990. Self-Selection and the Earnings of Immigrants: A Reply. American Economic Review 80 (1): 305-08.

Boyd, M. 1992. Gender, Visible Minority, and Immigrant Earnings Inequality: Reassessing an Employment Equity Premise, in V. Satzewich (ed.) Deconstructing a Nation: Immigration, Multiculturalism and Racism in '90s Canada, Halifax: Fernwood Publishing: 279-321.

Bratsberg B, Ragan JF, Nasir ZM (2002) The effect of naturalization on wage growth: A panel study of young male immigrants, Journal of Labor Economics 20 (3): 568597

Chiswick, B. 1978. The Effect of Americanization on the Earnings of Foreign-Born Men. Journal of Political Economy 86 (5) : 897-922.

- 1983. The Earnings and Human Capital of American Jews. Journal of Human Resources 18: 313-36.

- 1993. The Skills and Economic Status of American Jewry: Trends over the Last Half-Century. Journal of Labor Economics 11 (1): 229-42. 
DeVoretz, D. and J. Dean. 1996. The Economic Performance of Jewish Immigration to Canada: A Case of Double Jeopardy. Working paper. Research on Immigration and Integration in the Metropolis.

Ferrer A. and M. Riddell. 2002. The role of credentials in the Canadian labour market. Canadian Journal of Economics 35 (4): 87-905.

Isajiw, W., A. Sev'er, and L. Driedger, 1993. Ethnic identity and social mobility: A test of the "drawback model." Canadian Journal of Sociology 18: 179-98.

Isajiw, W., V. Satzewich, and E. Duvalko. 2002. Fourth Wave Immigrants from Ukraine, 1991-2001: Results of a New Study. CIUS seminar presentation. University of Toronto.

Jaeger, D. and M. Page. 1996. Degrees matter: new evidence on sheepskin effects in the returns to education. Review of Economics and Statistics 78 (4): 733-39.

Li, P. 1992. Race and Gender as Bases of Class Fractions and their Effects on Earnings. Canadian Review of Sociology and Anthropology, 29: 488-510.

Oaxaca, R. 1973. Male-female wage differentials in urban labor markets. International Economic Review 14: 693-709.

Pendakur, K. and Pendakur, R. 1998. The Colour of Money: Earnings Differentials Among Ethnic Groups in Canada. Canadian Journal of Economics 31(3): 518-48.

Reitz, J. and R. Breton. 1994. The Illusion of Difference: Realities of Ethnicity in Canada and the United States, Toronto: C. D. Howe Institute.

Stelcner, M. and N. Kyriazis. 1995. An empirical analysis of earnings among ethnic groups in Canada, International Journal of Contemporary Sociology 32, 41-79

Suzuki, M. 2002. Selective Immigration and Ethnic Economic Achievement: Japanese Americans before World War II. Explorations in Economic History 39: 254-81

Swidinsky, R. 1997. White-Visible Minority Earnings Differentials: A Comparison of Immigrant and Native-Born Canadians. Guelph, Ontario: University of Guelph, Department of Economics. 


\section{APPENDIX}

Table 1. Descriptive statistics for Canadian population groups

\begin{tabular}{|c|c|c|c|c|c|c|c|c|}
\hline \multirow{3}{*}{$\begin{array}{l}\text { Total (from } 18 \text { to } \\
65 \text { years old) } \\
\text { Age }\end{array}$} & \multicolumn{2}{|c|}{$\begin{array}{c}\text { Ukrainian } \\
\text { Immigrants }(U I)\end{array}$} & \multicolumn{2}{|c|}{$\begin{array}{c}\text { Non-Ukrainian } \\
\text { Immigrants (NUI) }\end{array}$} & \multicolumn{2}{|c|}{$\begin{array}{c}\text { Ukrainian } \\
\text { Canadian Born (UCB) }\end{array}$} & \multicolumn{2}{|c|}{$\begin{array}{c}\text { Non-Ukrainian } \\
\text { Canadian Born (NUCB) }\end{array}$} \\
\hline & Frequency & Percentage & Frequency & Percentage & Frequency & Percentage & Frequency & Percentage \\
\hline & 547 & & 63570 & & 11950 & & 242727 & \\
\hline$\frac{\text { Age }}{\text { Mean }}$ & 42.46 & & 41.55 & & 36.44 & & 37.33 & \\
\hline $\begin{array}{l}\text { Sex } \\
\text { Female } \\
\text { Male }\end{array}$ & $\begin{array}{l}246 \\
301\end{array}$ & $\begin{array}{l}45.00 \\
55.00\end{array}$ & $\begin{array}{l}29404 \\
34166\end{array}$ & $\begin{array}{l}46.30 \\
53.70\end{array}$ & $\begin{array}{l}5902 \\
6048\end{array}$ & $\begin{array}{l}49.40 \\
50.60\end{array}$ & $\begin{array}{l}113980 \\
128747\end{array}$ & $\begin{array}{l}47.00 \\
53.00\end{array}$ \\
\hline Marital status, \% & & & & & & & & \\
\hline $\begin{array}{l}\text { Divorced } \\
\text { Legally married } \\
\text { Separated } \\
\text { Never married } \\
\text { Widowed }\end{array}$ & $\begin{array}{c}48 \\
370 \\
20 \\
99 \\
10\end{array}$ & $\begin{array}{c}8.80 \\
67.60 \\
3.70 \\
18.10 \\
1.80\end{array}$ & $\begin{array}{c}4042 \\
43457 \\
2208 \\
12966 \\
897\end{array}$ & $\begin{array}{c}6.40 \\
68.40 \\
3.50 \\
20.40 \\
1.40\end{array}$ & $\begin{array}{c}929 \\
6456 \\
348 \\
4096 \\
121\end{array}$ & $\begin{array}{c}7.80 \\
54.00 \\
2.90 \\
34.30 \\
1.00\end{array}$ & $\begin{array}{c}20843 \\
124897 \\
7972 \\
86363 \\
2652\end{array}$ & $\begin{array}{c}8.60 \\
51.50 \\
3.30 \\
35.60 \\
1.10\end{array}$ \\
\hline $\begin{array}{l}\text { Highest degree, } \\
\text { certificate or } \\
\text { diploma } \%\end{array}$ & & & & & & & & \\
\hline $\begin{array}{l}\text { High school and } \\
\text { lower } \\
\text { Diploma or }\end{array}$ & 198 & 36.20 & 28444 & 44.70 & 5729 & 47.90 & 119732 & 49.30 \\
\hline $\begin{array}{l}\text { certificate (above } \\
\text { high school) }\end{array}$ & 202 & 36.90 & 20745 & 32.60 & 4124 & 34.50 & 81710 & 33.70 \\
\hline $\begin{array}{l}\text { Bachelor } \\
\text { Bachelor plus }\end{array}$ & 84 & 15.40 & 8623 & 13.60 & 1518 & 12.70 & 28853 & 11.90 \\
\hline $\begin{array}{l}\text { (bachelor+, } \\
\text { masters, medical) }\end{array}$ & 55 & 10.10 & 4799 & 7.50 & 541 & 4.50 & 11503 & 4.70 \\
\hline $\begin{array}{l}\text { Earned doctorate } \\
\text { Knowledge of } \\
\text { Official }\end{array}$ & 8 & 1.50 & 959 & 1.50 & 38 & 0.30 & 929 & 0.40 \\
\hline$\overline{\text { Languages, \% }}$ & & & & & & & & \\
\hline English only & $\begin{array}{c}456 \\
2\end{array}$ & $\begin{array}{c}83.40 \\
0.40\end{array}$ & $\begin{array}{c}51397 \\
1644\end{array}$ & $\begin{array}{c}80.90 \\
2.60\end{array}$ & $\begin{array}{c}11096 \\
4\end{array}$ & $\begin{array}{c}92.90 \\
0.00\end{array}$ & $\begin{array}{c}147778 \\
36880\end{array}$ & $\begin{array}{l}60.90 \\
15.20\end{array}$ \\
\hline $\begin{array}{l}\text { Both English and } \\
\text { French }\end{array}$ & 78 & 14.30 & 8404 & 13.20 & 848 & 7.10 & 58009 & 23.90 \\
\hline $\begin{array}{l}\text { Neither English } \\
\text { nor French } \\
\text { Home Language, }\end{array}$ & 11 & 2.00 & 2125 & 3.30 & 2 & 0.00 & 60 & 0.00 \\
\hline \% & & & & & & & & \\
\hline $\begin{array}{l}\text { English only } \\
\text { French only }\end{array}$ & $\begin{array}{c}343 \\
6\end{array}$ & $\begin{array}{c}62.70 \\
1.10\end{array}$ & $\begin{array}{l}35576 \\
2609\end{array}$ & $\begin{array}{c}56.00 \\
4.10\end{array}$ & $\begin{array}{c}11772 \\
51\end{array}$ & $\begin{array}{c}98.50 \\
0.40\end{array}$ & $\begin{array}{c}166758 \\
71775\end{array}$ & $\begin{array}{l}68.70 \\
29.60\end{array}$ \\
\hline $\begin{array}{l}\text { Both English and } \\
\text { French }\end{array}$ & 2 & 0.40 & 167 & 0.30 & 10 & 0.10 & 1034 & 0.40 \\
\hline $\begin{array}{l}\text { Other } \\
\text { Occupation (1991 }\end{array}$ & 196 & 35.80 & 25218 & 39.70 & 117 & 1.00 & 3160 & 1.30 \\
\hline $\begin{array}{l}\text { NOC), \% } \\
\text { Professional } \\
\text { (includes } \\
\text { managerial) }\end{array}$ & 197 & 36.00 & 19278 & 30.30 & 3637 & 30.40 & 72311 & 29.80 \\
\hline Skilled & 113 & 20.70 & 13301 & 20.90 & 2708 & 22.70 & 53825 & 22.20 \\
\hline Low Skill & 237 & 43.30 & 30991 & 48.80 & 5605 & 46.90 & 116591 & 48.00 \\
\hline $\begin{array}{l}\text { Weeks worked in } \\
\underline{1995}\end{array}$ & & & & & & & & \\
\hline $\begin{array}{l}\text { Mean } \\
\text { Wage income }\end{array}$ & 44.04 & & 43.75 & & 43.82 & & 43.40 & \\
\hline Mean, \$ & 30508.44 & & 28902.14 & & 28811.57 & & 28613.88 & \\
\hline
\end{tabular}


Table 2. Estimation of log-linear earnings model

\begin{tabular}{|c|c|c|c|c|}
\hline & $\begin{array}{l}\text { Ukrainian } \\
\text { Immigrants }\end{array}$ & $\begin{array}{l}\text { Non-Ukrainian } \\
\text { Immigrants }\end{array}$ & $\begin{array}{c}\text { Ukrainian } \\
\text { Canadian Born }\end{array}$ & $\begin{array}{l}\text { Non-Ukrainian } \\
\text { Canadian Born }\end{array}$ \\
\hline & $\mathrm{N}=541$ & $\mathrm{~N}=63,162$ & $\mathrm{~N}=11,950$ & $\mathrm{~N}=242,727$ \\
\hline Variables & \multicolumn{4}{|c|}{ Estimated coefficients (t-statistics) } \\
\hline \multirow{2}{*}{ (Constant) } & 4.539 & 4.702 & 4.268 & 4.387 \\
\hline & $(9.083)$ & $(107.451)$ & $(8.752)$ & $(267.632)$ \\
\hline \multirow{2}{*}{ AGEP } & $6.420 \mathrm{E}-02$ & 7.597E-02 & .123 & .115 \\
\hline & $(2.875)$ & $(40.941)$ & $(32.125)$ & $(136.233)$ \\
\hline \multirow{2}{*}{ AGESQ } & $-6.561 \mathrm{E}-04$ & $-7.929 \mathrm{E}-04$ & $-1.343 \mathrm{E}-03$ & $-1.248 \mathrm{E}-03$ \\
\hline & $(-2.500)$ & $(-36.541)$ & $(-28.136)$ & $(-119.080)$ \\
\hline \multirow{2}{*}{ YSIM } & $2.395 \mathrm{E}-02$ & $2.315 \mathrm{E}-02$ & & \\
\hline & $(2.778)$ & $(3.737)$ & - & - \\
\hline \multirow{2}{*}{ YSIMSQ } & $-2.895 \mathrm{E}-04$ & $-1.390 \mathrm{E}-03$ & & \\
\hline & $(-1.790)$ & $(-3.196)$ & - & - \\
\hline \multirow{2}{*}{ FEMALE } & -.499 & -.315 & -.405 & -.392 \\
\hline & $(-7.903)$ & $(-55.197)$ & $(-32.122)$ & $(-140.867)$ \\
\hline \multirow{2}{*}{ MARRIED } & $-6.649 E-02$ & $6.835 \mathrm{E}-02$ & $8.266 \mathrm{E}-02$ & $7.977 \mathrm{E}-02$ \\
\hline & $(-.876)$ & (9.889) & (5.662) & $(25.117)$ \\
\hline \multirow{2}{*}{ OLN } & .215 & $8.661 \mathrm{E}-02$ & & \\
\hline & $(.928)$ & (5.376) & - & - \\
\hline \multirow{2}{*}{ DIPL } & $9.388 \mathrm{E}-02$ & .117 & .105 & .103 \\
\hline & (1.218) & $(17.460)$ & $(7.185)$ & (32.009) \\
\hline \multirow{2}{*}{$\mathrm{BACH}$} & .138 & .215 & .233 & .254 \\
\hline & (1.347) & $(23.083)$ & $(10.828)$ & $(52.063)$ \\
\hline \multirow{2}{*}{ BACHPL } & $3.234 E-02$ & .281 & .280 & .340 \\
\hline & (.261) & (23.473) & $(8.543)$ & $(47.737)$ \\
\hline \multirow{2}{*}{ PHD } & .210 & .497 & .504 & .373 \\
\hline & $(.781)$ & $(20.822)$ & $(4.515)$ & $(16.523)$ \\
\hline \multirow{2}{*}{ SKL } & .281 & .177 & .223 & .204 \\
\hline & $(3.251)$ & $(23.585)$ & (13.454) & $(56.032)$ \\
\hline \multirow{2}{*}{ PROF } & .381 & .345 & .372 & .351 \\
\hline & $(4.612)$ & $(46.407)$ & $(22.186)$ & $(94.248)$ \\
\hline \multirow{2}{*}{ LNWKSWK } & .926 & .801 & .819 & .823 \\
\hline & $(15.789)$ & $(137.630)$ & $(60.761)$ & $(289.441)$ \\
\hline Adj. $R^{2}$ & .49 & .44 & .51 & .50 \\
\hline F-statistics & 37.99 & 3563.14 & 1059.72 & 22688.21 \\
\hline
\end{tabular}


Table 3. Estimated sheepskin effects

\begin{tabular}{lrrrr}
\hline \multirow{2}{*}{ Years of schooling } & $\begin{array}{c}\text { Ukrainian } \\
\text { Immigrants }\end{array}$ & $\begin{array}{c}\text { Non-Ukrainian } \\
\text { Immigrants }\end{array}$ & $\begin{array}{c}\text { Ukrainian } \\
\text { Canadian born }\end{array}$ & $\begin{array}{c}\text { Non-Ukrainian } \\
\text { Canadian born }\end{array}$ \\
\cline { 2 - 5 } \% of return due to sheepskin effect \\
\hline 5-8 Yrs Schooling & 2.5 & 0.517 & -1.013 & -0.346 \\
9 Years Schooling & 3.511 & 1.441 & -0.479 & 0.175 \\
10 Years Schooling & 3.8 & 1.7023 & 0.2 & 0.637 \\
11 Years Schooling & 5.5 & 2.981 & 0.187 & 1.2 \\
12 Years Schooling & 6.2 & 2.723 & 1 & 1.5 \\
13 Years Schooling & 9.5 & 4.761 & 4.2 & 3.9 \\
14-17 Years Schooling & 19.1 & 14.4 & 12.6 & 13 \\
18 More Years Schooling & 22.8 & 29.5 & 30.8 & 32.5 \\
\hline
\end{tabular}

Table 4. Estimation of citizenship effect on immigrant's earnings

\begin{tabular}{|c|c|c|}
\hline & Ukrainian Immigrants & Non-Ukrainian Immigrants \\
\hline Variables & \multicolumn{2}{|c|}{ Estimated coefficients (t-statistics) } \\
\hline \multirow[t]{2}{*}{ (Constant) } & 3.644 & 4.338 \\
\hline & $(7.280)$ & $(99.645)$ \\
\hline \multirow[t]{2}{*}{ AGEP } & .098 & .093 \\
\hline & $(4.389)$ & $(47.445)$ \\
\hline \multirow[t]{2}{*}{ AGESQ } & -.001 & -.001 \\
\hline & $(-3.701)$ & $(-41.767)$ \\
\hline \multirow[t]{2}{*}{ FEMALE } & -.475 & -.319 \\
\hline & $(-7.082)$ & $(-51.227)$ \\
\hline \multirow[t]{2}{*}{ MARRIED } & -.099 & .058 \\
\hline & $(-1.297)$ & $(8.132)$ \\
\hline \multirow[t]{2}{*}{ OLN } & .419 & .180 \\
\hline & $(1.777)$ & $(10.418)$ \\
\hline \multirow[t]{2}{*}{ CTZN } & .232 & .159 \\
\hline & (2.638) & (21.677) \\
\hline \multirow[t]{2}{*}{ DIPL } & .009 & .123 \\
\hline & $(.109)$ & $(16.772)$ \\
\hline \multirow[t]{2}{*}{$\mathrm{BACH}$} & .096 & .199 \\
\hline & $(.871)$ & (19.607) \\
\hline \multirow[t]{2}{*}{ BACHPL } & -.123 & .245 \\
\hline & $(-.948)$ & (18.824) \\
\hline \multirow[t]{2}{*}{ PHD } & -.064 & .466 \\
\hline & $(-.232)$ & (17.978) \\
\hline \multirow[t]{2}{*}{ SKL } & .411 & .242 \\
\hline & (4.508) & $(29.485)$ \\
\hline \multirow[t]{2}{*}{ PROF } & .526 & .429 \\
\hline & (6.129) & (52.917) \\
\hline \multirow[t]{2}{*}{ LNWEEKS } & .926 & .804 \\
\hline & $(15.518)$ & $(138.620)$ \\
\hline Adj. $\mathrm{R}^{2}$ & 0.488 & 0.414 \\
\hline F-statistics & 41.427 & 3619.094 \\
\hline
\end{tabular}


Table 5. Descriptive statistics for the U.S. population groups

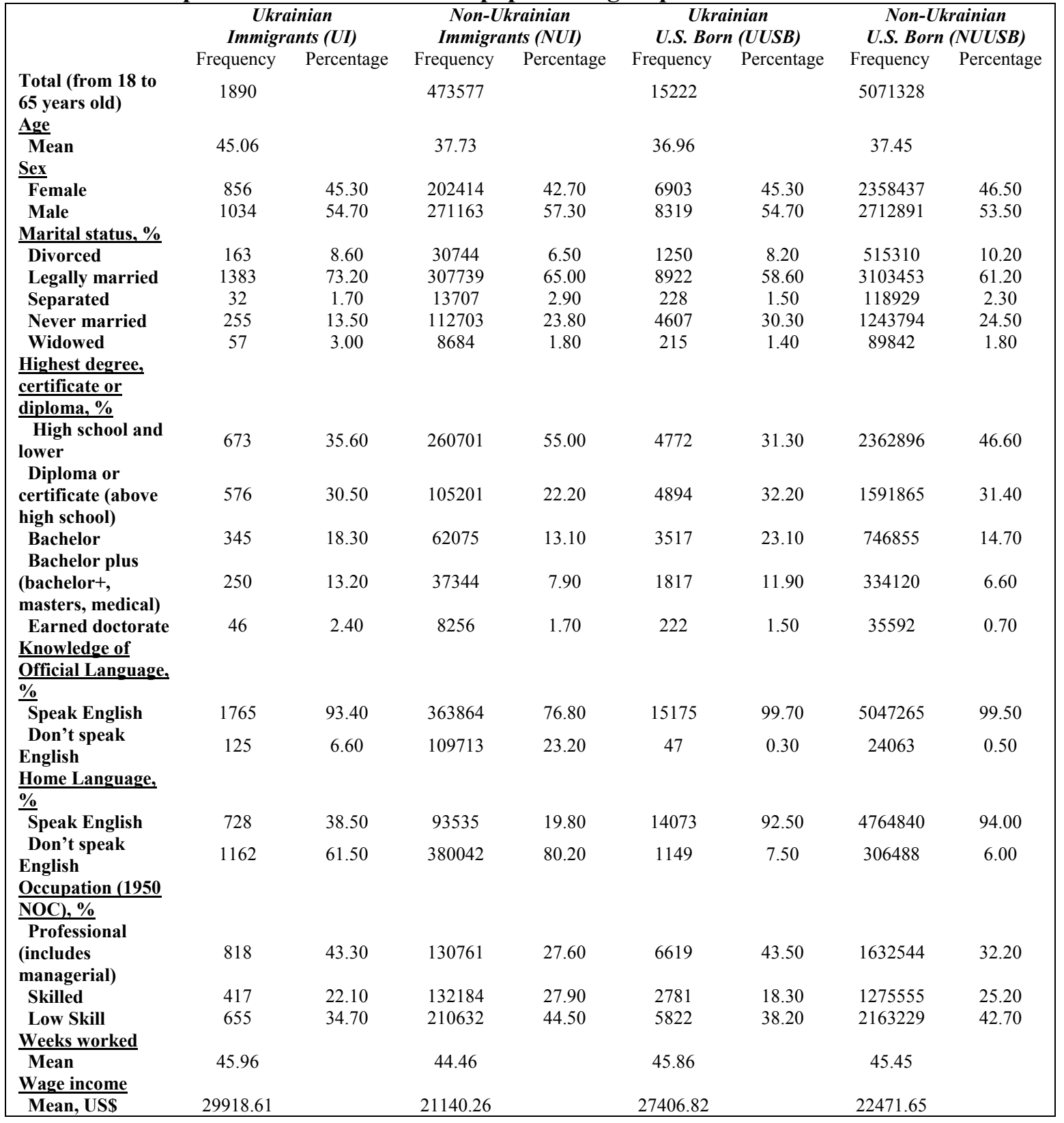


Figure 1. Entry gates for Ukrainian immigrants to Canada, 1991-2001

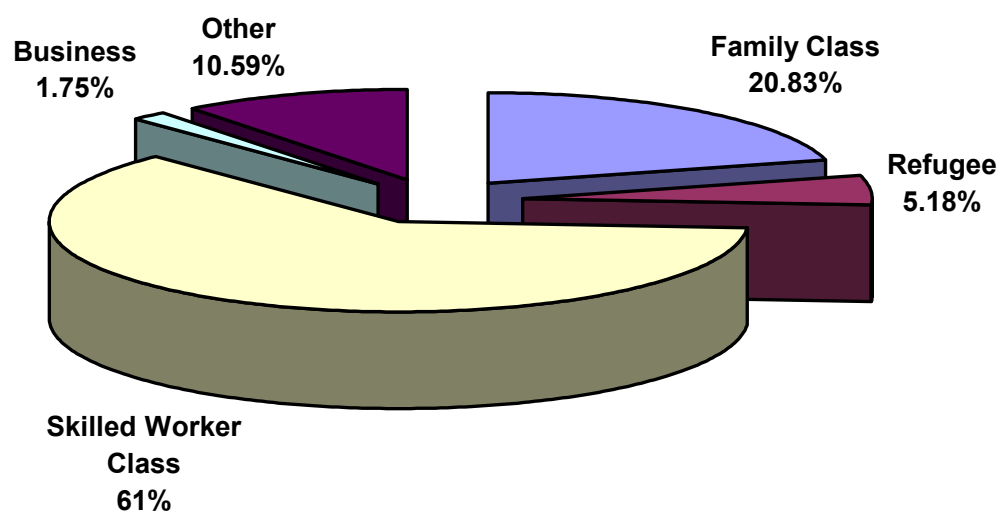

Source: Landed Immigrant Data System (LIDS)

Figure 2. Entry gates for non-Ukrainian immigrants to Canada, 1991-2001

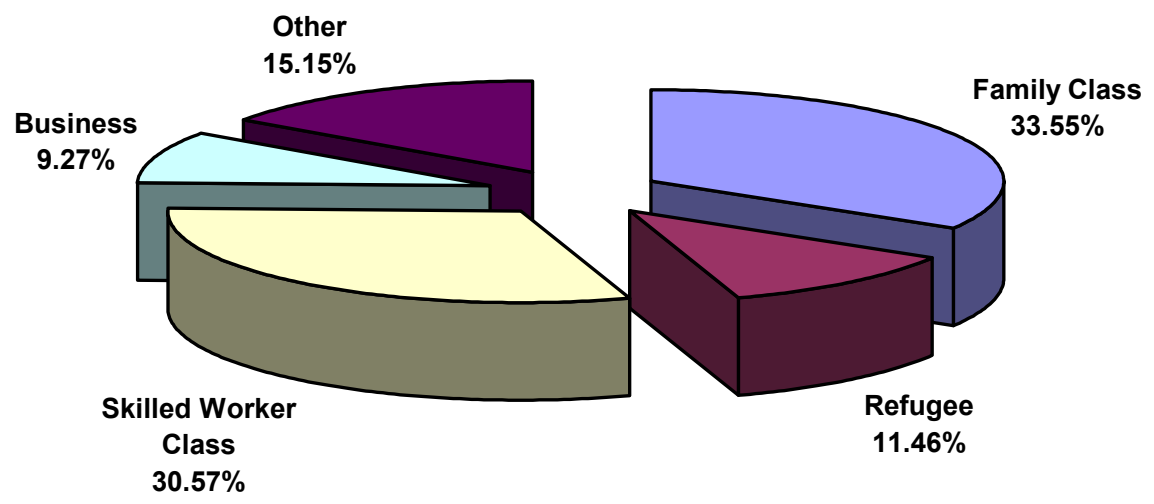

Source: Landed Immigrant Data System (LIDS) 
Figure 3. Province of destination for Ukrainian immigrants to Canada, 1991-2001

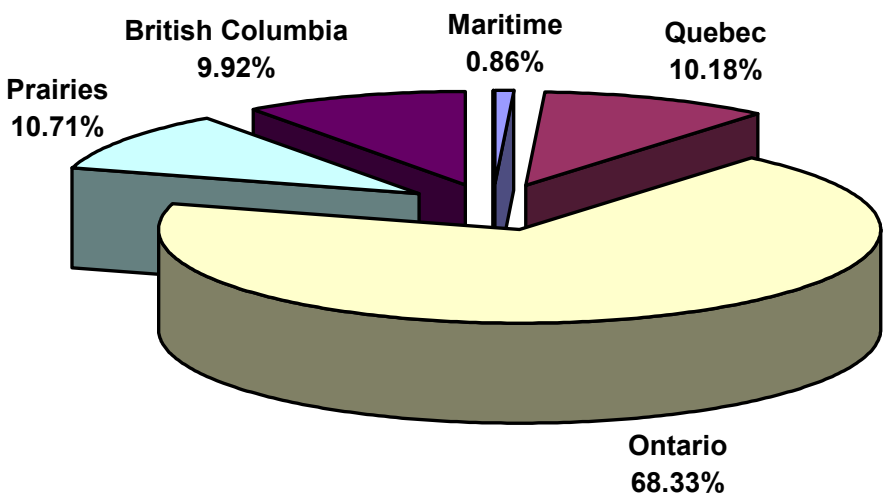

Source: Landed Immigrant Data System (LIDS)

Figure 4. Province of destination for non-Ukrainian immigrants to Canada, 1991-2001

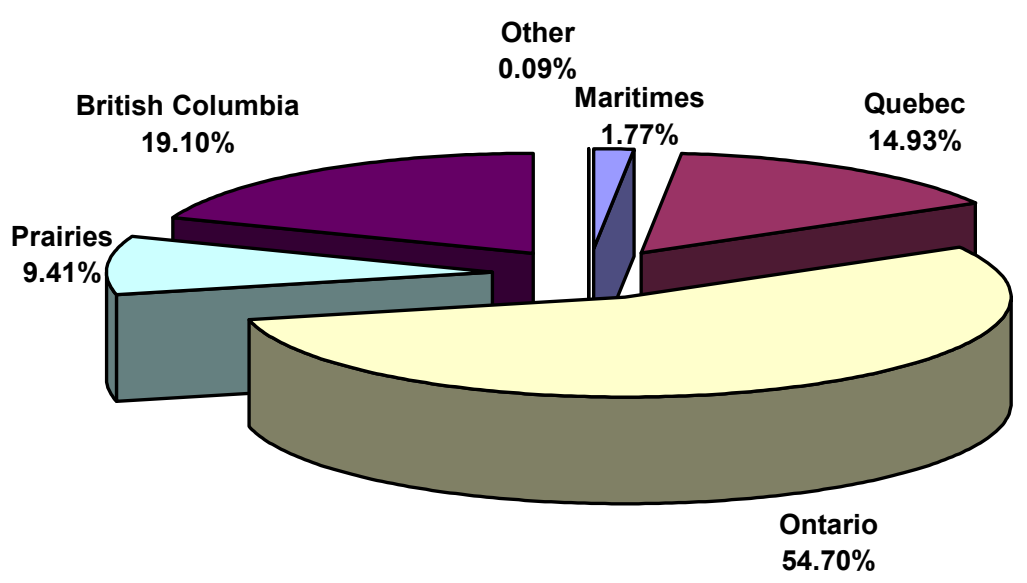

Source: Landed Immigrant Data System (LIDS) 
Figure 5. Age-earnings profile for Ukrainian Immigrants to Canada (UI), NonUkrainian Immigrants to Canada (NUI), Ukrainian Canadian Born (UCB) and Non-Ukrainian Canadian Born (NUCB)

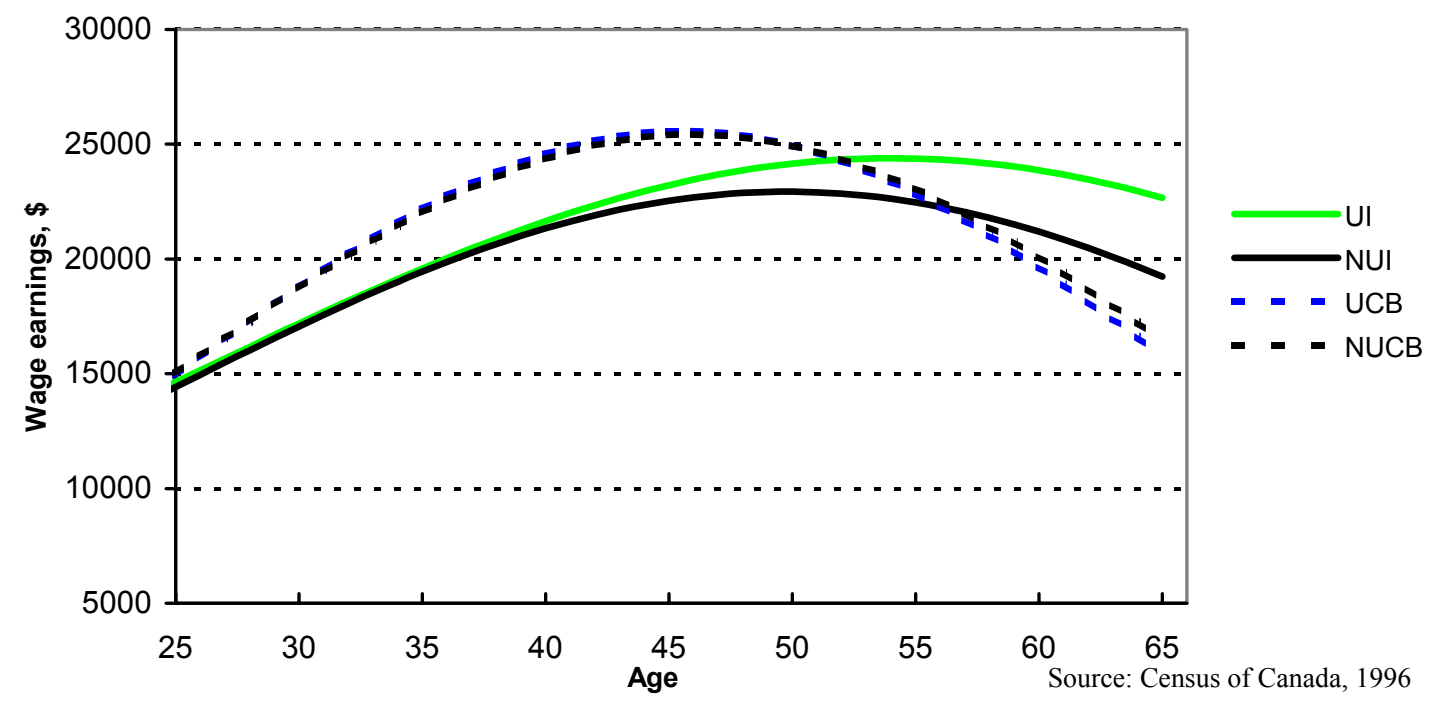

Figure 6. Assimilation profile for Ukrainian Immigrants (UI) and Non-Ukrainian Immigrants (NUI) in Canada

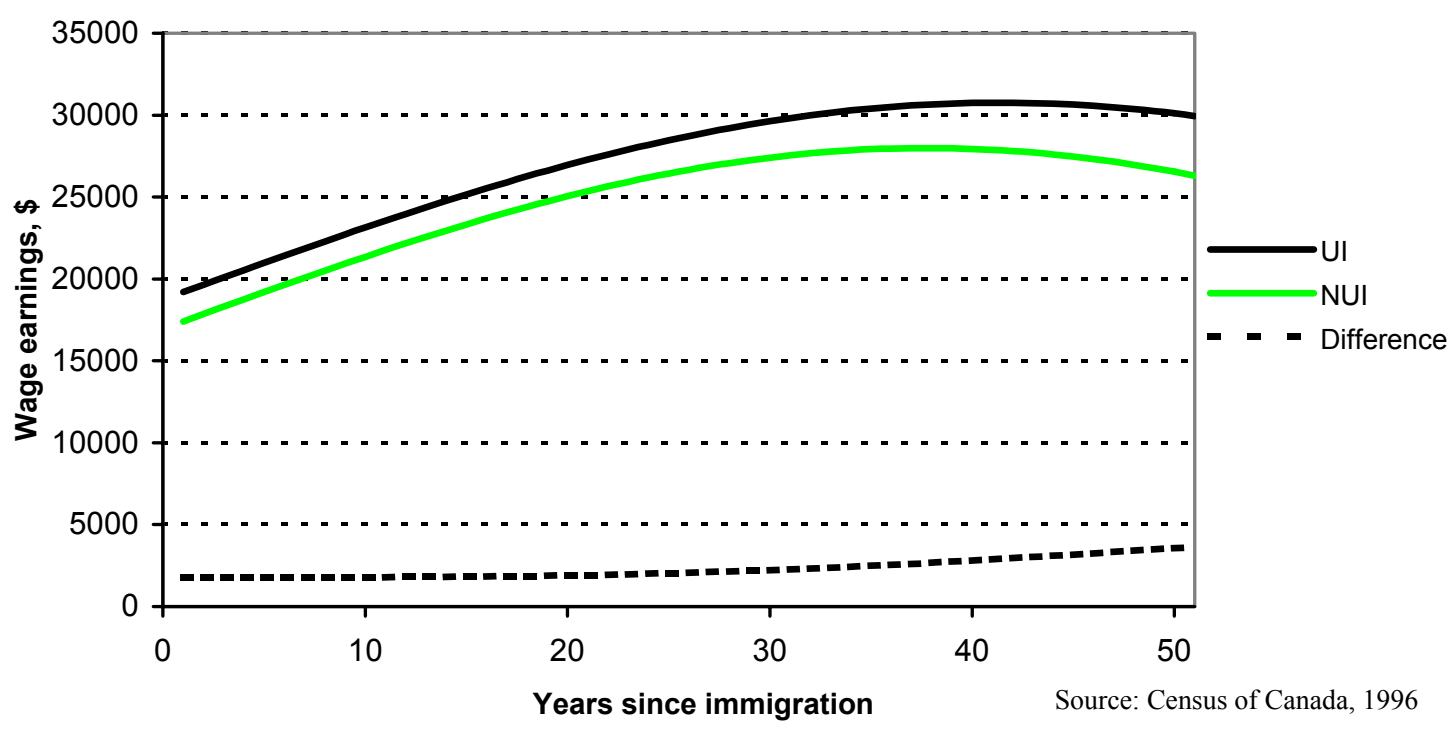


Figure 7. Age-earnings profiles for Ukrainians Canadian Born (UCB), Ukrainian Immigrants Canadian citizens (UI_C) and Ukrainian Immigrants non-citizens of Canada (UI_NC)

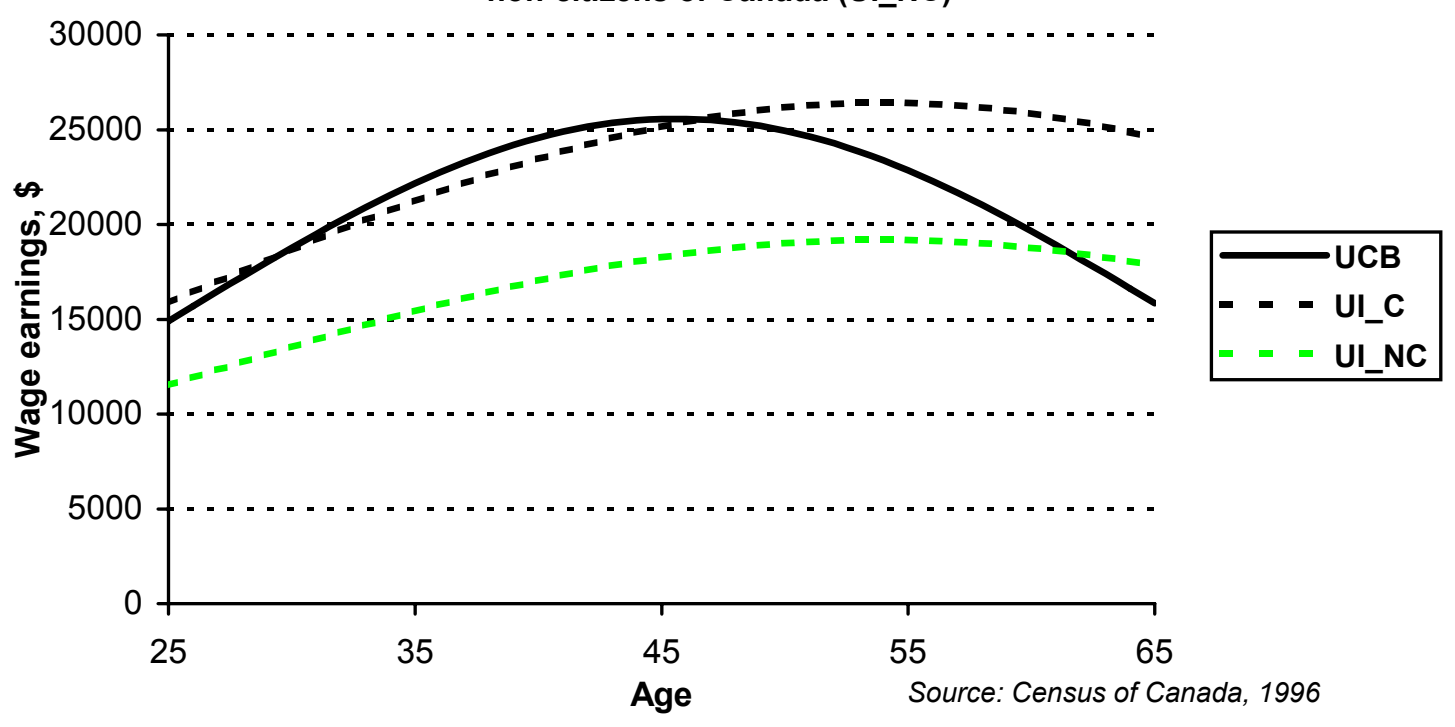

Figure 8. Age-earnings profiles for Ukrainian Immigrants to the U.S. (UI_US), Non-Ukrainian Immigrants to the U.S. (NUI_US), Ukrainian U.S. born (UUSB), and Non-Ukrainian U.S. born (NUUSB)

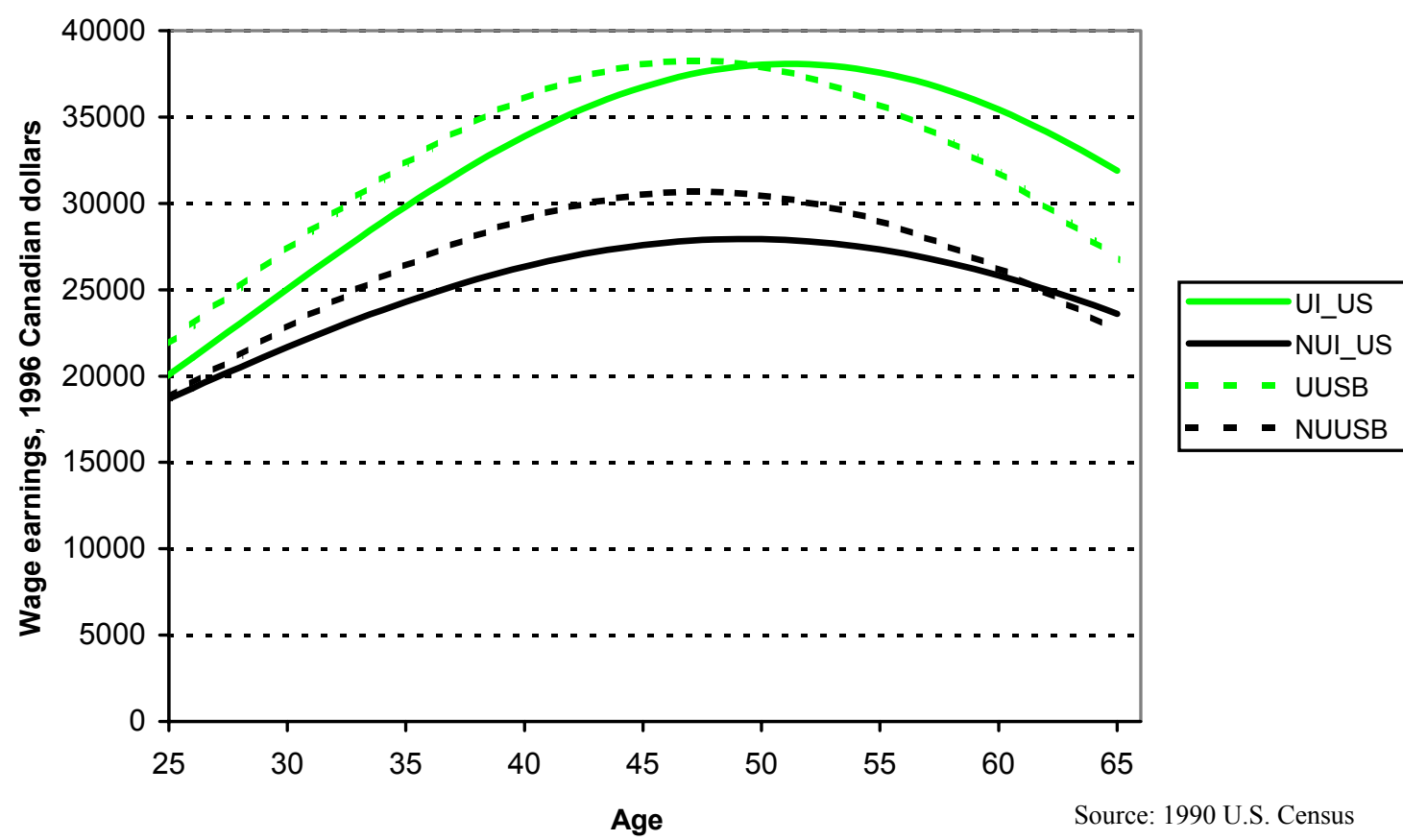


Figure 9. Age-earnings profiles of Ukrainian Immigrants to Canada (UI_CA) and Ukrainian Immigrants to the U.S. (UI_US)

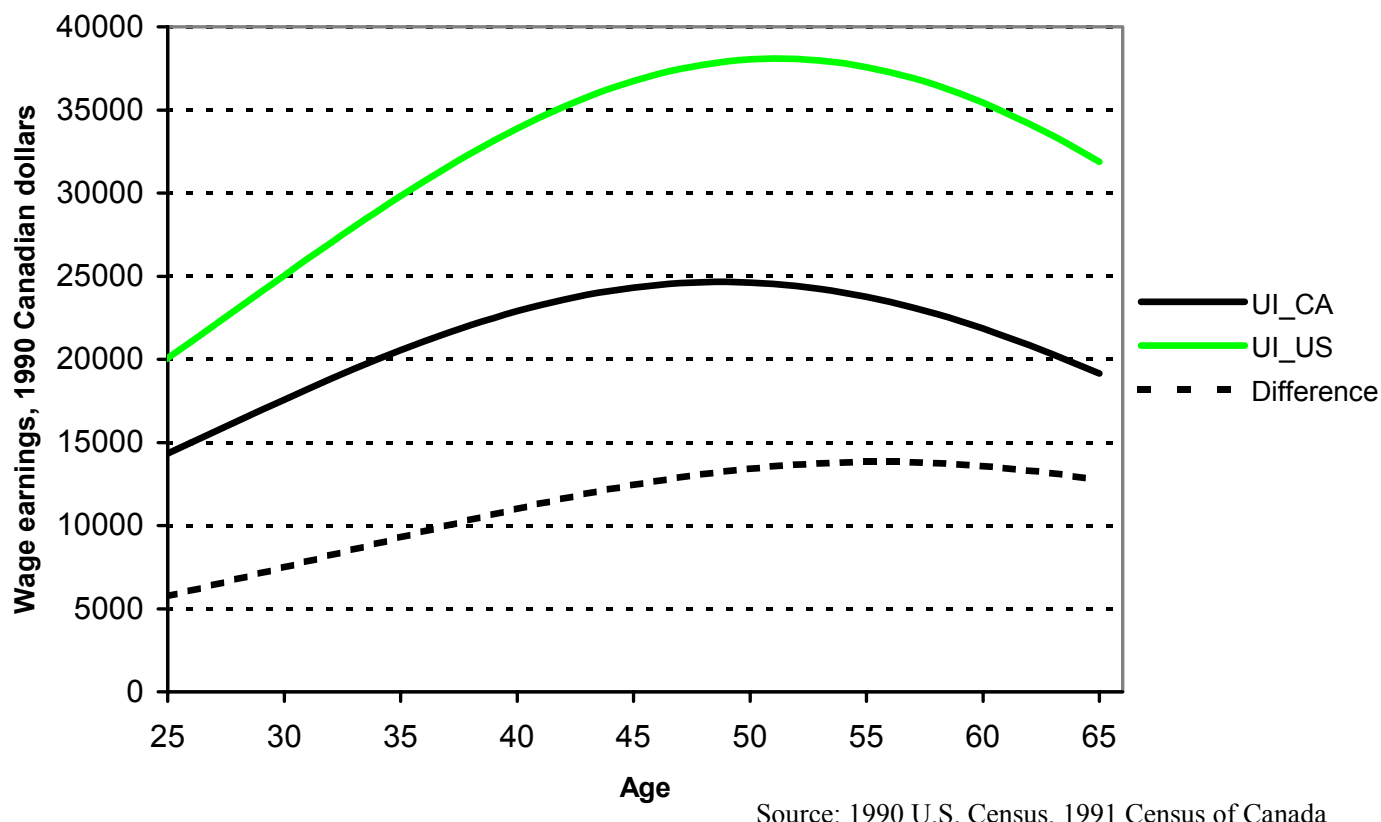




\section{IZA Discussion Papers}

\begin{tabular}{|c|c|c|c|c|}
\hline No. & Author(s) & Title & Area & Date \\
\hline 899 & $\begin{array}{l}\text { M. Karanassou } \\
\text { H. Sala } \\
\text { D. J. Snower }\end{array}$ & $\begin{array}{l}\text { Unemployment in the European Union: } \\
\text { Institutions, Prices, and Growth }\end{array}$ & 2 & $10 / 03$ \\
\hline 900 & $\begin{array}{l}\text { M. C. Berger } \\
\text { G. C. Blomquist } \\
\text { K. Sabirianova Peter }\end{array}$ & $\begin{array}{l}\text { Compensating Differentials in Emerging Labor } \\
\text { and Housing Markets: Estimates of Quality of } \\
\text { Life in Russian Cities }\end{array}$ & 4 & $10 / 03$ \\
\hline 901 & $\begin{array}{l}\text { P. F. Orazem } \\
\text { M. Vodopivec }\end{array}$ & $\begin{array}{l}\text { Do Market Pressures Induce Economic } \\
\text { Efficiency: The Case of Slovenian } \\
\text { Manufacturing, 1994-2001 }\end{array}$ & 4 & $10 / 03$ \\
\hline 902 & $\begin{array}{l}\text { P. Frijters } \\
\text { M. A. Shields } \\
\text { S. Wheatley Price }\end{array}$ & $\begin{array}{l}\text { Immigrant Job Search in the UK: Evidence from } \\
\text { Panel Data }\end{array}$ & 1 & $10 / 03$ \\
\hline 903 & $\begin{array}{l}\text { S. Girma } \\
\text { H. Görg }\end{array}$ & $\begin{array}{l}\text { Evaluating the Causal Effects of Foreign } \\
\text { Acquisition on Domestic Skilled and Unskilled } \\
\text { Wages }\end{array}$ & 2 & $10 / 03$ \\
\hline 904 & $\begin{array}{l}\text { S. P. Jenkins } \\
\text { P. Van Kerm }\end{array}$ & $\begin{array}{l}\text { Trends in Income Inequality, Pro-Poor Income } \\
\text { Growth and Income Mobility }\end{array}$ & 1 & $10 / 03$ \\
\hline 905 & $\begin{array}{l}\text { D. Weichselbaumer } \\
\text { R. Winter-Ebmer }\end{array}$ & $\begin{array}{l}\text { Rhetoric in Economic Research: The Case of } \\
\text { Gender Wage Differentials }\end{array}$ & 7 & $10 / 03$ \\
\hline 906 & $\begin{array}{l}\text { D. Weichselbaumer } \\
\text { R. Winter-Ebmer }\end{array}$ & $\begin{array}{l}\text { A Meta-Analysis of the International Gender } \\
\text { Wage Gap }\end{array}$ & 7 & $10 / 03$ \\
\hline 907 & $\begin{array}{l}\text { A. Dupuy } \\
\text { L. Borghans }\end{array}$ & $\begin{array}{l}\text { Supply and Demand, Allocation and Wage } \\
\text { Inequality: An International Comparison }\end{array}$ & 1 & $10 / 03$ \\
\hline 908 & M. Leonardi & Product Demand Shifts and Wage Inequality & 1 & $10 / 03$ \\
\hline 909 & M. Leonardi & $\begin{array}{l}\text { Firm Heterogeneity in Capital/Labor Ratios and } \\
\text { Wage Inequality }\end{array}$ & 1 & $10 / 03$ \\
\hline 910 & $\begin{array}{l}\text { P. Díaz-Vázquez } \\
\text { D. Snower }\end{array}$ & $\begin{array}{l}\text { On-the-Job Training, Firing Costs and } \\
\text { Employment }\end{array}$ & 5 & $10 / 03$ \\
\hline 911 & J. Wagner & $\begin{array}{l}\text { Are Nascent Entrepreneurs Jacks-of-All-Trades? } \\
\text { A Test of Lazear's Theory of Entrepreneurship } \\
\text { with German Data }\end{array}$ & 5 & $10 / 03$ \\
\hline 912 & $\begin{array}{l}\text { D. Checchi } \\
\text { A. Filippin }\end{array}$ & An Experimental Study of the POUM Hypothesis & 1 & $10 / 03$ \\
\hline 913 & $\begin{array}{l}\text { S. Pivnenko } \\
\text { D. DeVoretz }\end{array}$ & $\begin{array}{l}\text { The Recent Economic Performance of Ukrainian } \\
\text { Immigrants in Canada and the U.S. }\end{array}$ & 1 & $10 / 03$ \\
\hline
\end{tabular}

An updated list of IZA Discussion Papers is available on the center's homepage www.iza.org. 